\title{
Assessing the social dimension of frailty in old age: A systematic review
}

\author{
Bruno Bessa $^{\mathrm{a}, \mathrm{b}, *}$, Oscar Ribeiro ${ }^{\mathrm{b}, \mathrm{c}}$, Tiago Coelho ${ }^{\mathrm{d}}$ \\ ${ }^{a}$ Higher Institute of Social Service of Porto (ISSSP), Av. Dr. Manuel Teixeira Ruela, 370, 4460-362 Senhora da Hora, Portugal \\ ${ }^{\mathrm{b}}$ Institute of Biomedical Sciences Abel Salazar, University of Porto (ICBAS.UP), Rua de Jorge Viterbo Ferreira, 228, 4050-313 Porto, Portugal \\ ${ }^{\mathrm{c}}$ Department of Education and Psychology, University of Aveiro (DEP.UA), Center for Health Techcology and Services Research (CINTESIS), Campus Universitário de \\ Santiago, 3810-193 Aveiro, Portugal \\ ${ }^{\mathrm{d}}$ School of Health, Polytechnic Institute of Porto, Rua Dr. António Bernardino de Almeida, 400, 4200-072 Porto, Portugal
}

\author{
A B S T R A C T
}

Keywords:

Frailty

Social networks

Loneliness

Isolation

Social support

Social activities

\begin{abstract}
Introduction: Different concepts of frailty have resulted in different assessment tools covering distinct dimensions. Despite the growing recognition that there is an association between frailty and social factors, there's a lack of clarity on what is being assessed in terms of "social aspects" of frailty.

Objective: This paper provides a review of frailty assessment instruments (screening tools and severity measures) with a special focus on their social components.

Methods: Systematic review of studies published in English between 2001 and March 2018 in the PubMed database using a combination of MeSH Terms and logical operators through inclusion and exclusion criteria.

Results: A total of 27 assessment tools including at least one social question were identified. Three instruments focuses exclusively on social frailty, whereas the weight of social dimensions in the other instruments ranges between $5 \%$ and $43 \%$. Social activities, social support, social network, loneliness and living alone were the social concepts most represented by the social components of the various frailty instruments.

Conclusion: Social components of frailty vary from instrument to instrument and cover the concepts of social isolation, loneliness, social network, social support and social participation.
\end{abstract}

\section{Introduction}

Resulting from an increasingly aging world population, frailty has become an emerging public health priority (Cesari et al., 2016). It is presented as a state of increased vulnerability that describes elderly people with a high risk of adverse health outcomes such as falls, hospitalizations, disability, permanent institutionalization, and death (Rodríguez-Mañas et al., 2013; Yeolekar \& Sukumaran, 2014; Zaslavsky et al., 2012).

Although the theoretical foundations of frailty are well established in the literature, the concept has developed over time, leading to a variety of one- and multidimensional models (Buckinx et al., 2015; Clegg, Young, Iliffe, Rikkert, \& Rockwood, 2013; Gobbens, Luijkx, Wijnen-Sponselee, \& Schols, 2010; Hogan, MacKnight, Bergman, \& Steering Committee, 2003; Markle-Reid \& Browne, 2003; Mohandas, Reifsnyder, Jacobs, \& Fox, 2011; Zaslavsky et al., 2012). Among the most well-known models of frailty (Clegg et al., 2013), the biological one emerges as a one-dimensional conceptualization based on physical functioning that is based on five components - weight loss, exhaustion, low energy expenditure, slowness, and weakness (Fried et al., 2001); the deficit accumulation model assumes a combination of symptoms, diseases, conditions, and disability that is expressed in a Frailty Index (Cesari, Gambassi, Van Kan, \& Vellas, 2014; Mitnitski, Mogilner, \& Rockwood, 2001; Rockwood \& Mitnitski, 2007) that allows a multidimensional understanding of the concept (Searle, Mitnitski, Gahbauer, Gill, \& Rockwood, 2008; Walston \& Bandeen-Roche, 2015).

Whereas the biomedical perspective is predominant in the literature (Clegg et al., 2013), contemporary definitions of frailty postulate the presence of a complex interaction between physical, psychological, social and environmental factors (Buckinx et al., 2015; Hogan et al., 2003; Markle-Reid \& Browne, 2003; Mohandas et al., 2011; Zaslavsky et al., 2012). Different models of frailty were thus translated into different operational definitions of the concept, and to different screening tools and severity measures (Buta et al., 2016; de Vries et al., 2011; Dent, Kowal, \& Hoogendijk, 2016). According to Sternberg, Schwartz, Karunananthan, Bergman, and Clarfield, 2011 systematic literature review on the identification of frailty, the most commonly used components are physical function, gait speed, and cognition; death, disability and institutionalization are the most common outcomes. Although these authors highlight the need for further clarification of the role of cognitive and mood elements in the frailty construct, no specific mention was made on its social dimension. 
Regardless of the growing recognition that there is a clear association between social factors (e.g., socioeconomic and social support) and frailty, the social components of frailty have only been recently explored within frailty assessment tools (Coelho, 2015; de Vries et al., 2011; Sutton et al., 2016; Theou, Brothers, Mitnitski, \& Rockwood, 2013). Bunt, Steverink, Olthof, Schans, and Hobbelen, 2017 in a recent scope review of "social frailty" in older adults concluded that it can be understood as a multidimensional concept with a diversity of general and/or social resources, social behaviours and activities, and selfmanagement abilities which all have a function in adding or affecting social needs fulfilment. By these means, social frailty can be defined as a continuum of being at risk of losing, or having lost, resources that are important for fulfilling one or more basic social needs during the life span. The authors also argue that there may be relevant factors to the concept of social frailty which differ in their importance and which can be underestimated and neglected, suggesting the need for a specification of these factors. In this sense, this paper provides a review of frailty assessment instruments with social components. It is intended to understand how social components have been operationalized and the extent of importance they are given in such screening tools and severity measures.

\section{Methodology}

A review of articles published and available in the PubMed electronic database was carried out within a time horizon from January 2001 to March 2018. The following Medical Subject Headings (MeSH) and logical operators were used as strategy: "frail or frailty" AND "aged or elderly or older" AND "social or social isolation or loneliness or social support or social network or social marginalization or socioeconomic factors".

The articles were selected using the following inclusion criteria: a) reference to frailty as the main term; b) a sample consisting of persons aged 60 years or over; c) studies published in English; d) studies that describe and test the operationalization of multidimensional assessment tool specifically developed for the assessment and identification of frailty; e) studies including the assessment of frailty by at least one social variable/question. As exclusion criteria: a) review articles; b) studies with modified versions of the original frailty assessment tool, with the exception of the Frailty Index; c) studies with subsequent use of the frailty assessment tools.

After analysing the abstracts obtained in the initial research, authors proceeded to the full reading of the articles whenever the methodological part of the study was less enlightening. References were also analysed to include and identify studies that presented other tools, as well as systematic reviews of frailty instruments. No checklist was applied to assess the methodological quality of the studies. A grid was built based on the study objectives, assessment methodology and operationalization of frailty, in order to analyse the articles.

\section{Results}

The review procedure is described in Fig. 1 . Of the 2257 potentially eligible articles, 22 articles attending all inclusion and exclusion criteria were selected, corresponding to 22 assessment tools. After consulting frailty literature, 5 frailty assessment tools were added, making a total of 27 instruments. No other studies were identified after a bibliographic analysis of the selected articles. Table 1 presents each of the frailty instrument and its social components.

The self-reported Barber Questionnaire (Postal Screening Questionnaire- PSQ) (Barber, Wallis, \& McKeating, 1980) is a 9 item multidimensional screening tool which identifies individuals who may be at risk of dependency. This questionnaire assesses functional status, psychosocial functioning, neurosensory deficits, self-reported health, social support and previous year hospital admissions. It's easy to understand, self-administer and positive answers to any item are considered an indicator of being in "at risk" state.

The Frailty Staging System (FSS) (Cacciatore et al., 2005; Lachs et al., 1990) is a functional impairment index divided into seven domains: disability, mobility, cognitive function, visual function, auditory function, urinary continence and social support, distributed by 11 items that are scored whenever there is a loss of function. The social dimension is operationalized with a question that indicates the presence or absence of social support and allows the identification of the social network.

The Sherbrooke Postal Questionnaire (SPQ) (Hebert, Bravo, KornerBitensky, \& Voyer, 1996) is a tool for the screening of communitydwelling elderly at risk for functional decline. It comprises six items about living alone, medication, walking, eyesight, hearing and memory. The individual is considered to be in functional risk if one or more physical factors are present or if he does not return the questionnaire. In this tool, living alone is not considered a risk factor.

The Frailty Index (FI) results from an accumulation of deficits. It can be easily constructed from any database containing binary deficits, counting the number of deficits present and dividing by the number of total deficits considered (Mitnitski et al., 2001; Searle et al., 2008). In the present review, eight studies using the FI were found: (FI(1)(Myers, Drory, Goldbourt, \& Gerber, 2014); FI(2)(McKenzie, Ouellette-Kuntz, \& Martin, 2015); FI(3)(Ma et al., 2016); FI(4) (Young, Glaser, Spector, \& Steves, 2016); FI(5) (Bäckman et al., 2017); FI(6) (Dent, Dal Grande, Price, \& Taylor, 2017); and (FI-J) (Yamanashi et al., 2015) and Evaluative Frailty Index for Physical Activity (EFIPA) (de Vries, Staal, Olde Rikkert, \& Nijhuis-van der Sanden, 2013). Each of them presents different items of social domain related to work, social isolation, loneliness, social activities, social network, social support, housing problems, lifestyle and socio-demographics characteristics.

The Groningen Frailty Indicator (GFI) (Schuurmans, Steverink, Lindenberg, Frieswijk, \& Slaets, 2004; Steverink, Slaets, Schuurmans, \& van Lis, 2001) is a screening tool for determining the level of frailty in institutionalized or community-dwelling individuals. The GFI consists of 15 items that focus on the loss of functions and resources in four domains of functioning: physical (mobility, physical fitness, vision, hearing, nutrition and morbidity), psychological (mood and anxiety), cognitive (memory) and social (emotional isolation).

The Vulnerable Elders Survey-13 (VES-13) (Saliba et al., 2001) was developed to identify vulnerable community-dwelling older people, defined as persons aged 65 and older at risk of death or functional decline. The final score is given by 13 questions, taking into consideration age, self-rated health status, and functional disabilities. The age score is given according to the age range, with 0 points for people between $65-74$ years old, 1 point for ages between $75-84$ and 3 points for age equal to or greater than 85 years.

The Frailty Index Comprehensive Geriatric Assessment (FI-CGA) is a tool intended to simplify the clinical assessment of frailty (Jones, Song, Mitnitski, \& Rockwood, 2005). It is a FI built on the basis of a Comprehensive Geriatric Assessment (CGA) standard. Specifically, the FICGA is constituted by an Impairment Index, and by a Comorbidity Index, being its final score obtained by the sum of both indexes divided by 14 . While the Comorbidity Index aims to assess the burden of disease, the Impairment Index is a multidimensional tool composed by ten domains: cognition, emotion, communication, mobility, balance, urinary and faecal continence, nutrition, activities of daily living and social domain. Here the FI-CGA scores on the existence of formal home support and if the person lives alone.

The Edmonton Frail Scale (EFS) (Rolfson, Majumdar, Tsuyuki, Tahir, \& Rockwood, 2006) assesses frailty in nine domains: cognition, general health status, functional independence, social support, medication use, nutrition, mood, continence and functional performance. It is composed of 11 questions. Social support is assessed by the existence of someone who can meet one's needs. The maximum score is 17 , representing the highest level of frailty possible. It is presented as a scale of easy handling and application, allowing the evaluation of frailty in 


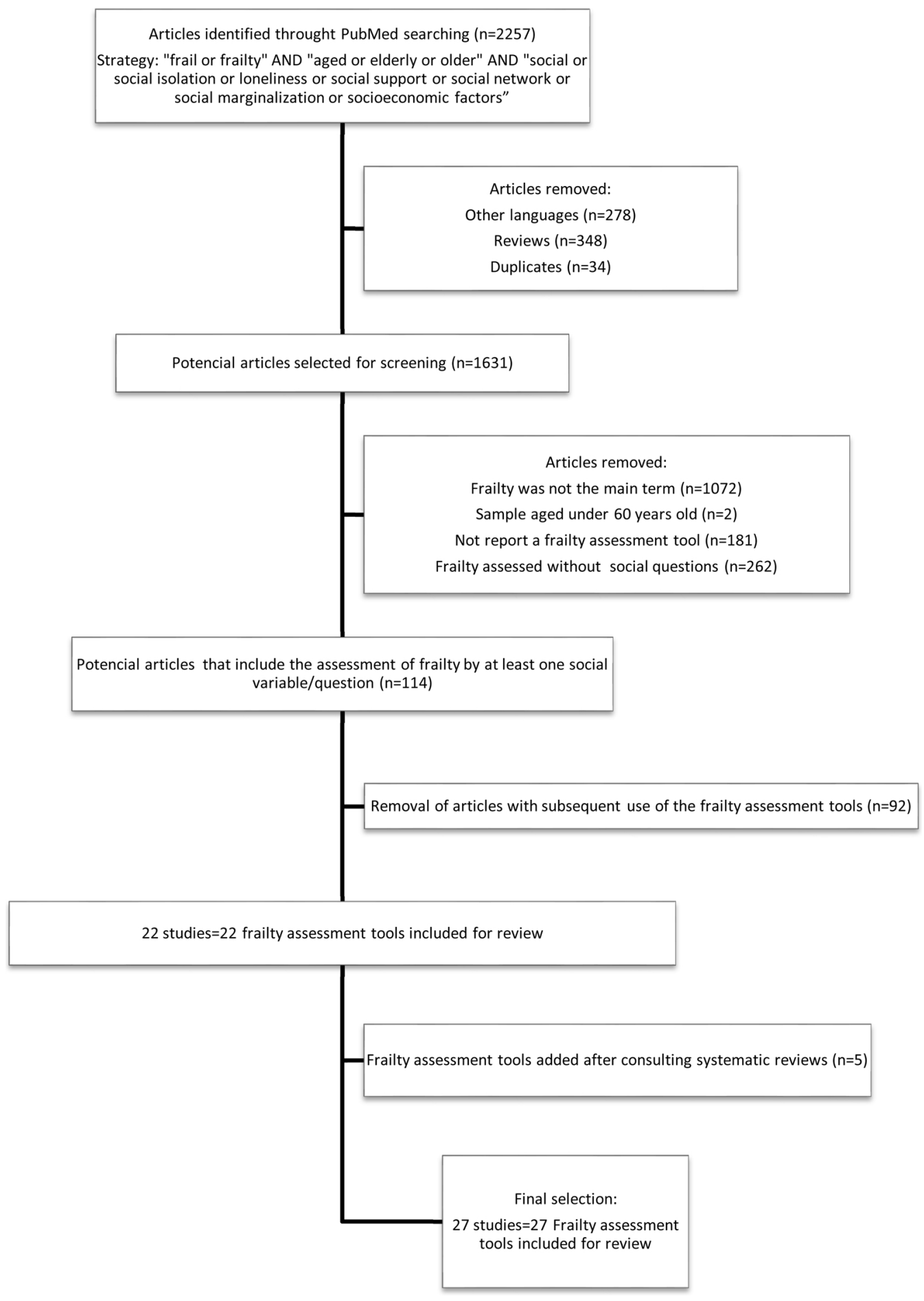

Fig. 1. Flow diagram of Frailty Assessment Tools selection.

different degrees.

The Prisma-7 (Raîche, Hébert, \& Dubois, 2008) developed from the Program on Research for Integrating Services for the Maintenance of Autonomy (PRISMA Project)(Hébert, Durand, Dubuc, \& Tourigny, 2003), is a community-dwelling self-administered screening questionnaire. It consists of seven questions (yes/no) that explore sociodemographic variables, autonomy and support; three or more positive answers identify elderly individuals at risk of disability. Prisma-7 is the only assessment tool found that includes gender as a frailty component.

Resulting from the Integral Conceptual Model of Frailty (ICMF), the Tilburg Frailty Indicator (TFI) (Gobbens, van Assen, Luijkx, Wijnen-
Sponselee, \& Schols, 2010) is a self-report assessment tool composed by two parts: Part A includes questions on the determinants of frailty, divided by ten questions on sociodemographic data, lifestyle, morbidity, life events and environment. These variables are not scored, nor are they part of the final score in assessing frailty; Part B assesses frailty through 15 items divided physical, psychological and social dimensions. Also deriving from the ICMF, the Comprehensive Frailty Assessment Instrument (CFAI) (De Witte et al., 2013a) is a screening tool for assessing frailty in community-dwelling people that has no clinical judgments. It is a fast and easy self-administration tool, whose final score is given by the different quotation of 23 factors. CFAI assesses 
Table 1

Social components present in the frailty assessment tools.

\begin{tabular}{|c|c|c|c|c|}
\hline \multicolumn{2}{|l|}{ Frailty assessment tool } & \multicolumn{3}{|c|}{ Questions/Items referring to social components } \\
\hline & & \multicolumn{2}{|l|}{$\begin{array}{l}\mathrm{N} \text { items } \\
\text { (Total) }\end{array}$} & $\mathrm{N}(\%)$ \\
\hline \multicolumn{2}{|l|}{$\begin{array}{l}\text { Postal Screening Questionnaire } \\
\quad \text { (PSQ) }\end{array}$} & 9 & $\begin{array}{l}\text { Do you live on your own? } \\
\text { Are you without a relative you could call on for help? } \\
\text { Are you confined to your home through ill health? }\end{array}$ & $3(33)$ \\
\hline $\begin{array}{l}\text { Frailty Staging System } \\
\quad \text { (FSS) }\end{array}$ & & 11 & Who will able to help you in case of illness or emergency? & $1(9)$ \\
\hline $\begin{array}{l}\text { Sherbrooke Postal Questionnaire } \\
\quad \text { (SPQ) }\end{array}$ & & 6 & Do you live alone? & $1(17)$ \\
\hline \multirow[t]{8}{*}{$\begin{array}{l}\text { Frailty Index } \\
\quad \text { (FI) }\end{array}$} & FI (1) & 40 & $\begin{array}{l}\text { Work limitations; } \\
\text { Social activities limitations; } \\
\text { Loneliness. }\end{array}$ & $3(8)$ \\
\hline & FI (2) & 42 & $\begin{array}{l}\text { Changes in social activities; } \\
\text { Social isolation; } \\
\text { Loneliness. }\end{array}$ & $3(7)$ \\
\hline & FI (3) & 68 & $\begin{array}{l}\text { Smoking and drinking; } \\
\text { Participation in social activities; } \\
\text { Physical exercise; } \\
\text { Work; } \\
\text { Housework; } \\
\text { Sleep quality. }\end{array}$ & $6(9)$ \\
\hline & FI (4) & 39 & $\begin{array}{l}\text { Social network (During the past } 4 \text { weeks, to what extent has your physical health or emotional problems } \\
\text { interfered with your normal social activities with family, friends, neighbours, or groups?) } \\
\text { Social activities (During the past } 4 \text { weeks, how much of the time has your physical health or emotional } \\
\text { problems interfered with your social activities - like visiting friends, relatives, etc.?) }\end{array}$ & $2(5)$ \\
\hline & FI (5) & 38 & $\begin{array}{l}\text { Do you feel lonely? } \\
\text { Daily contact with other people through meetings, phone, contacts, emails, etc. }\end{array}$ & $2(5)$ \\
\hline & FI (6) & 35 & $\begin{array}{l}\text { Problems with transport when you want to go out; } \\
\text { Marital status; } \\
\text { Family's money situation; } \\
\text { Current family structure (lives alone). }\end{array}$ & $4(11)$ \\
\hline & FI-J & 15 & $\begin{array}{l}\text { Less outdoor activity; } \\
\text { Fewer hobbies or interests; } \\
\text { Less contact with neighbours; } \\
\text { Less friendships other than neighbours. }\end{array}$ & $4(27)$ \\
\hline & EFIPA & 50 & $\begin{array}{l}\text { Do you feel lonely? } \\
\text { When you need help, are there people who are willing and able to help you? } \\
\text { Are there activities that someone else has taken over for you recently? } \\
\text { Are there enough organized activities for you nearby? } \\
\text { Do you have problems getting out for organized activities (e.g., problems with transportation to get to } \\
\text { them)? } \\
\text { Do you have any housing problems? } \\
\text { Do you have enough help from professionals? }\end{array}$ & $7(14)$ \\
\hline $\begin{array}{l}\text { Groningen Frailty Indicator } \\
\quad(\text { GFI) }\end{array}$ & & 15 & $\begin{array}{l}\text { Do you sometimes experience emptiness around yourself? } \\
\text { Do you sometimes miss people around yourself? } \\
\text { Do you sometimes feel abandoned? }\end{array}$ & $3(20)$ \\
\hline $\begin{array}{l}\text { Vulnerable Elders Survey-13 } \\
\text { (VES-13) }\end{array}$ & & 13 & Age & $1(8)$ \\
\hline \multicolumn{2}{|c|}{$\begin{array}{l}\text { Frailty Index - Comprehensive Geriatric Assessment } \\
\qquad \text { (FI - CGA) }\end{array}$} & 14 & $\begin{array}{l}\text { Social: } \\
\text { Institutionalized; } \\
\text { Uses formal home supports; } \\
\text { Living alone (Deficit) }\end{array}$ & $1(7)$ \\
\hline \multicolumn{2}{|l|}{$\begin{array}{l}\text { Edmonton Frail Scale } \\
\text { (EFS) }\end{array}$} & 11 & When you need help, can you count on someone who is willing and able to meet your needs? & $1(9)$ \\
\hline \multicolumn{2}{|l|}{ Prisma-7 } & 7 & $\begin{array}{l}\text { Are you older than } 85 \text { years? } \\
\text { Are you male? } \\
\text { If you need help, can you count on someone close to you? }\end{array}$ & $3(43)$ \\
\hline \multicolumn{2}{|l|}{$\begin{array}{l}\text { Tilburg Frailty Indicator } \\
\text { (TFI) }\end{array}$} & 15 & $\begin{array}{l}\text { Do you live alone? } \\
\text { Do you sometimes miss having people around you? } \\
\text { Do you receive enough support from other people? }\end{array}$ & $3(20)$ \\
\hline \multicolumn{2}{|c|}{$\begin{array}{l}\text { Comprehensive Frailty Assessment Instrument } \\
\text { (CFAI) }\end{array}$} & 23 & $\begin{array}{l}\text { There are plenty of people I can lean on when I have problems; } \\
\text { There are many people I can trust completely; } \\
\text { There are enough people I feel close to; } \\
\text { Social Network } 1 \text {; } \\
\text { Social Network 2; } \\
\text { Social Network } 3 \text {. }\end{array}$ & $6(26)$ \\
\hline \multicolumn{2}{|l|}{$\begin{array}{l}\text { Social Frailty Phenotype } \\
\text { (SFP) }\end{array}$} & 6 & $\begin{array}{l}\text { Living alone; } \\
\text { Absence of a person to help with ADL; } \\
\text { Infrequent family contact; } \\
\text { Infrequent friend/neighbour contact; } \\
\text { Absence of a confident; } \\
\text { Lack of support for daily living. }\end{array}$ & $6(100)$ \\
\hline
\end{tabular}


Table 1 (continued)

\begin{tabular}{|c|c|c|c|}
\hline Frailty assessment tool & \multicolumn{2}{|r|}{ Questions/Items referring to social components } & \multirow[b]{2}{*}{$\mathrm{N}(\%)$} \\
\hline & $\begin{array}{l}\mathrm{N} \text { items } \\
\text { (Total) }\end{array}$ & & \\
\hline $\begin{array}{l}\text { Easycare Two-Step Older Persons } \\
\text { Screening }\end{array}$ & 14 & $\begin{array}{l}\text { Loneliness; } \\
\text { Social network. }\end{array}$ & $2(14)$ \\
\hline (Easycare-TOS) & 8 & Social context: safety, environment, social network, social activities. & $1(13)$ \\
\hline $\begin{array}{l}\text { Gérontopôle Frailty Screening Tool } \\
\text { (GFST) }\end{array}$ & 6 & Does your patient live alone? & $1(17)$ \\
\hline $\begin{array}{l}\text { Comprehensive Model of Frailty } \\
\text { (CMF) }\end{array}$ & 44 & $\begin{array}{l}\text { Living alone or with their family members; } \\
\text { Frequency of attending social activities; } \\
\text { Having a spouse or a child to confide with when they need emotional support. }\end{array}$ & $3(7)$ \\
\hline $\begin{array}{l}\text { Kihon Checklist } \\
\text { (KCL) }\end{array}$ & 25 & $\begin{array}{l}\text { Do you sometimes visit your friends? } \\
\text { Do you turn to your family or friends for advice? } \\
\text { Do you go out at least once a week? } \\
\text { Do you go out less frequently compared to last year? }\end{array}$ & $4(16)$ \\
\hline $\begin{array}{l}\text { Questionnaire to define Social Frailty Status } \\
\text { (QSFS) }\end{array}$ & 5 & $\begin{array}{l}\text { Do you go out less frequently compared with last year? } \\
\text { Do you sometimes visit your friends? } \\
\text { Do you feel you are helpful to friends or family? } \\
\text { Do you live alone? } \\
\text { Do you talk with someone every day? }\end{array}$ & $5(100)$ \\
\hline $\begin{array}{l}\text { Frailty Groupe Iso-Ressource Evaluation } \\
\text { FRAGIRE }\end{array}$ & 19 & $\begin{array}{l}\text { Do you use Internet? } \\
\text { Do you participate in sport activities (sport, art, etc.)? }\end{array}$ & $2(11)$ \\
\hline $\begin{array}{l}\text { interRAI Home Care Frailty Scale } \\
\text { iRHCFS }\end{array}$ & 29 & Social engagement: decline, reduced or withdrawal from social activities. & $3(10)$ \\
\hline $\begin{array}{l}\text { Social Frailty Index } \\
\text { (SFI) }\end{array}$ & 7 & $\begin{array}{l}\text { Living alone; } \\
\text { No education; } \\
\text { Absence of a confidant; } \\
\text { Infrequent contact (visits, calls or request for help); } \\
\text { Infrequent social activities; } \\
\text { Financial difficulty (To a great extent); } \\
\text { Social economic deprivation (1-2 room flats \& others). }\end{array}$ & $7(100)$ \\
\hline
\end{tabular}

frailty in four dimensions: physical, psychological, social and environmental. The social dimension is constituted by two measures similar to those proposed by the ICMF, but operationalized in different ways: social loneliness and social support network (De Witte et al., 2013b).

The Social Frailty Phenotype (SFP) (Garre-Olmo, Calvó-Perxas, López-Pousa, De Gracia Blanco, \& Vilalta-Franch, 2013) was operationally defined using a deficit accumulation model, with questions about living alone, social network, and social support. The authors in their study, adopting the hypothesis that the accumulation of deficits increases frailty, created operational definitions of three separate phenotypes of frailty (Physical Frailty Phenotype, Mental Frailty Phenotype, Social Frailty Phenotype) composed by different indicators that are rated as present / absent.

The Easycare Two-Step Older Persons Screening (Easycare-TOS) (van Kempen et al., 2013; van Kempen, Schers, Philp, Olde Rikkert, \& Melis, 2015) is presented as being the only instrument specifically designed to be used in primary care and is divided into two steps. The first one works as patient screening, assessing in 14 questions the functioning of somatic, psychological and social domains. The patient is then classified as frail, not frail or unclear; those considered frail or unclear go on to the second step in which a structured evaluation will be performed by a clinical professional. The decision of whether there is frailty or not is based on a clinical reasoning rather than on a final score, and derives from implicit and explicit information on the factors that make the patient more or less frail. While the first step assess the social domain through questions of loneliness and social network, the second step asses the social context: safety, environment, social network, and social activities.

The Gérontopôle Frailty Screening Tool (GFST) (Tavassoli et al., 2014) was developed to be administered to persons aged 65 years and over, without physical disability and acute clinical disease. It consists of an initial questionnaire about symptoms and/or signs divided into six components of frailty (living alone, weight loss, fatigue, mobility, memory and slowness), which aims to attract the attention of the general practitioner to the presence of a state of frailty. The social component is reflected in a single question related to the presence of social isolation. In the second part, the general practitioner expresses his/her own view about the frailty status of the individual, through a subjective evaluation.

The Comprehensive Model of Frailty (CMF) (De Witte et al., 2013a; Kwan, Lau, \& Cheung, 2015), is an instrument composed by 44 items that are scored in the presence of a deficit. The CMF results from the addition of 12 items that assess the deficits in the psychological, social/ family, environmental and economic domains to a FI with 32 items (FI32) concerning to physical, functional and psychocognitive well-being. Regarding the social domain, the deficits were indicated by living alone and having social activities at a frequency less than weekly and having no spouse or children to confide with.

The Kihon Checklist (Arai \& Satake, 2015; Satake et al., 2016) was developed by the Japanese Ministry of Health, Labor and Welfare to identify vulnerable older adults as those at a higher risk of becoming dependent. It is a self-reporting tool that consists of 25 (yes/no) questions divided into the following domains: instrumental, social, activities of daily living, physical functions, nutritional status, oral function, cognitive function and depressive mood. All the items are scored in the presence of a deficit, and the higher the score in each domain, the greater the risk of requiring support or care in that domain. In the social domain, the KCL presents 4 questions related to social network, social support and social participation.

The self-reported Questionnaire to define Social Frailty Status (QSFS) used in the study of Makizako et al. (2015) aims to evaluate the state of social frailty through simple questions in the following domains: daily social activity, social role and social relationships. It presents two questions taken from the Kihon-Checklist (Fukutomi et al., 2015) and one question from the Geriatric Depression Scale (Yesavage, 1988). Of the seven items initially proposed, only five were used to define social frailty status: living alone, going out less frequently than last year, not visiting friends at times, not feeling helpful to friends or family, and finally not talking with someone every day. Participants who reported the presence of none of these social deficits were 
considered to be non-frail; those who reported 1 deficit were considered to be pre-frail; and who reported 2 or more deficits were considered to be frail.

The Frailty Groupe Iso-Ressource Evaluation (FRAGIRE) (Vernerey et al., 2016) is a frailty-screening instrument that can be administrated by a public health social worker without medical training. It presents 19 questions regarding physical, cognitive, functional, psychosocial/family, and environmental, cultural, sexual and nutritional status. We only consider the socio-cultural dimension indicated by the authors, however, the authors included questions about loneliness and financial situation as belonging to the environmental domain. It turns out that FRAGIRE is the only Frailty assessment tool that reports the use of the internet as a socio-cultural factor.

The interRAI Home Care Frailty Scale (Morris, Howard, \& Steel, 2016) is derived from a subset of items of the interRAI Home Care assessment instrument. It provides a comprehensive view of the person's risk of decline and is composed by 29 items belonging to 6 categories: function, movement, cognition and communication, social life, nutrition and clinical symptoms. In the social domain, this assessment tool presents three questions related with the social engagement: decline, reduced and withdrawal from social activities.

The Social Frailty Index (SFI) (Teo, Gao, Nyunt, Wee, \& Ng, 2017), is an index constructed on the basis of data collected from the Singapore Longitudinal Ageing Studies Wave 1 (SLAS-1) cohort (Niti, Yap, Kua, Tan, \& Ng, 2008). Social Frailty was operationalized and assessed through socio-demographic variables and self-reported survey questionnaires in 7 questions about: living alone, no education, absence of a confident, infrequent contact, infrequent social activities, financial difficulty and socioeconomic depravation.

In overall, results show that besides SFP, QSFS and SFI, which included items assessing social frailty status only, the assessment tools presenting greater proportion of social items are the PRISMA-7 (43\%), PSQ (33\%), FI-J (27\%) and CFAI (26\%). On the other hand, there is a small number of social issues in favour of physical and psychological issues in FI (2) (7\%), FI (4) (5\%) and FI (5) (5\%) being these the instruments that present a smaller emphasis attributed to the social dimension.

Although there are questions with different formulations, it is possible to group the social items of each tool into different domains (see Table 2). Social activities and social support were the domains more often represented, followed by social network, loneliness and living alone. Social activities include questions about frequency and participation, and social support includes questions related to emotional and instrumental support, emergency need and support in general. As for the social network, the questions allow identifying the existence, composition, size and strength of the social network. The assessment tools directly question the experienced feeling of emotional loneliness or social loneliness. Socio-demographic, lifestyle, work, social context, cultural and social role are the less numerically expressive domains.

\section{Discussion}

To date, and to the best of the authors' knowledge, this is a first review carried out on the diverse set of social components included in frailty assessment tools. Most relevant results show that (i) there's a great diversity of social components being assessed in the currently available screening tools and severity measures of frailty; (ii) when compared to the physical and psychological dimensions, the social dimension has the less weight in the detection of frailty within each instrument (with the exception of three instruments); (iii) most frequent social components include social activities, social support, social network, loneliness and living alone.

When considering the diversity and extent of social components found in this review, there are ambiguous and subjective questions distributed by the different frailty assessment tools. For example, the question "Does the patient ever miss the presence of other people around him?" of the GFI (Steverink et al., 2001) similar to the question "Do you sometimes miss having people around you?" of the TFI (Gobbens, van Assen et al., 2010) were considered in the present review as belonging to the loneliness domain. However, according to the TFI authors the question is related to social relations. Due to the subjective nature of this question, the pertinence arises from the fact that the same question can assess different factors of social frailty, reason why it is defended that the factors that constitute social frailty should be mirrored in clear and concrete questions concerning what is in fact intended to assess.

The existence of different evaluation instruments reflects the ambiguity present in the concept and in the operationalization of frailty over the past decade (Dent et al., 2016; Mohandas et al., 2011; van Kan et al., 2010), and may cause problems of evidence in comparing studies regarding the prevalence, risk factors and intervention outcomes (Aguayo et al., 2017; Bouillon et al., 2013; Collard, Boter, Schoevers, \& Oude Voshaar, 2012; Karunananthan, Wolfson, Bergman, Béland, \& Hogan, 2009; Roppolo, Mulasso, Gobbens, Mosso, \& Rabaglietti, 2015). It is known that the most widely used multidimensional assessment tool in frailty assessment studies is TFI and there is still no standard gold frailty measurement (Dent et al., 2016; Sutton et al., 2016); however because it is not a fixed index, the FI is the only tool capable and more likely to cover a greater diversity of social factors, giving a greater weight and percentage to this domain due to the freedom of choice of the items that each investigator can introduce (de Vries et al., 2011; Mitnitski et al., 2001).

The relationships between frailty and sociodemographic variables such as being female, advanced age, low educational level, low socioeconomic status and housing context are already explored in the literature (Alvarado, Zunzunegui, Beland, \& Bamvita, 2008; Collard et al., 2012; de Labra et al., 2018; Etman, Burdorf, Van der Cammen, Mackenbach, \& Van Lenthe, 2012; Guessous et al., 2014; Herr, Robine, Aegerter, Arvieu, \& Ankri, 2015; St John, Montgomery, \& Tyas, 2013; Woo, Zheng, Leung, \& Chan, 2015), however, it is one of the least expressive domains. Depending on the model of frailty, these can be included as determinants or as components of frailty, giving as an example the residential environment that emerges as a determinant in ICMF and that in CFAI appears as a frailty component. The introduction of some of these variables as social components of frailty should be discussed in further studies.

Looking at the most frequent social components, social support is a complex term that may cover a diverse set of domains (Haber, Cohen, Lucas, \& Baltes, 2007; Moser, Stuck, Silliman, Ganz, \& Clough-Gorr, 2012; Sherbourne \& Stewart, 1991). Mirroring its ambiguity, we have as example a study that considers social support as being part of the environmental domain (Chen, Chen, Lue, Tseng, \& Wu, 2014). Being one of the most consensual factors of social frailty, the operationalization of this concept can bring benefits in the understanding and detection of frailty. Allied to this concept of social support we have social network. From the assessment tools found, the CFAI formulates a question that allows the measurement of the size of the family network by dividing the answer into three levels. However, no assessment tool formulates questions about the family arrangement nor does it distinguish the type of family support. Family-dependent older people with a restricted support network are more present among frail elder who have high levels of loneliness (Hoogendijk, Suanet, Dent, Deeg, \& Aartsen, 2016; Op Het Veld et al., 2015). Moreover, multigenerational family arrangement can contribute to the increase of social support received and consequently to the reduction of frailty (Duarte, Fernandes, Rodrigues, \& Nóbrega, 2013).

Loneliness, on the other hand, is neither a one-dimensional construct nor synonym of objective social isolation. People may be alone without feeling lonely and may feel lonely when they are with others. Hence, an alternative name for loneliness has been "perceived social isolation" (Hawkley, 2015). A recent study points to the existence of a relationship between frailty and psychosocial factors, and that 
Table 2

Division of different social items by domains.

\begin{tabular}{|c|c|c|c|}
\hline Domains & Assessment Tool & Questions & Answers \\
\hline \multirow[t]{33}{*}{ Social support } & PSQ & Are you without a relative you could call on for help? & Yes; \\
\hline & & & No. \\
\hline & FSS & Who will able to help you in case of illness or emergency? & $\begin{array}{l}\text { Actual and potential caregivers must be identified (names, } \\
\text { addresses and phone numbers of persons who can help in } \\
\text { case of illness or emergency). }\end{array}$ \\
\hline & FI(6) & Problems with transport when you want to go out; & Yes; \\
\hline & & & Sometimes; \\
\hline & & & No. \\
\hline & EFIPA & $\begin{array}{l}\text { When you need help, are there people who are willing and able to help } \\
\text { you? }\end{array}$ & $\begin{array}{l}\text { Most of the time; } \\
\text { Sometimes; } \\
\text { Rarely. }\end{array}$ \\
\hline & EFIPA & Do you have enough help from professionals? & Most of the time; \\
\hline & & & Sometimes; \\
\hline & & & Rarely. \\
\hline & EFS & When you need help, can you count on someone who is willing and & Always ; \\
\hline & & able to meet your needs? & Sometimes; \\
\hline & & & Never. \\
\hline & PRISMA-7 & If you need help, can you count on someone close to you? & Yes; \\
\hline & & & No. \\
\hline & TFI & Do you receive enough support from other people? & Yes; \\
\hline & & & No; \\
\hline & CFAI & I know many people whom I can totally trust; & 1- I completely disagree; \\
\hline & CFAI & There are enough people whom I feel a bond; & 2- I disagree; \\
\hline & CFAI & There are plenty of people whom I can rely on when I am in trouble. & 3- I neither agree/nor disagree; \\
\hline & & & 4- I agree; \\
\hline & & & 5- I completely agree. \\
\hline & SFP & Do you have family and/or friends you could ask for help if you & Yes; \\
\hline & & needed assistance? & No. \\
\hline & SFP & Is there anyone special (a couple, friend, family member, and/or & Yes; \\
\hline & & $\begin{array}{l}\text { neighbour) that you can trust and talk to about personal matters and } \\
\text { your feelings? }\end{array}$ & No. \\
\hline & SFP & In the past 3 months, have you failed to receive help from others with & Yes; \\
\hline & & $\begin{array}{l}\text { shopping, food preparation, housecleaning, ironing or other personal } \\
\text { activities even though you needed help? }\end{array}$ & No. \\
\hline & $\mathrm{CMF}$ & $\begin{array}{l}\text { Having a spouse or a child to confide with when they need emotional } \\
\text { support; }\end{array}$ & Having no spouse or children to confide with. \\
\hline & KCL & Do you turn to your family or friends for advice? & Yes; \\
\hline & & & No. \\
\hline & SFI & Do you have someone to confide in? & Yes; \\
\hline & & & No. \\
\hline \multirow[t]{32}{*}{ Social Activities } & $\mathrm{FI}(1)$ & Social activities limitations; & Major limitation; \\
\hline & & & Minor limitation; \\
\hline & & & No limitation. \\
\hline & $\mathrm{FI}(2)$ & Changes in Social Activities; & $\begin{array}{l}\text { No decline in participation in social activities (last } 90 \text { days); } \\
\text { Decline in participation in social activities (last } 90 \text { days). }\end{array}$ \\
\hline & FI(3) & Participation in social activities; & Yes; \\
\hline & & & Occasionally; \\
\hline & & & No. \\
\hline & FI(4) & During the past 4 weeks, how much of the time has your physical & All of the time $=1$ \\
\hline & & health or emotional problems interfered with your social activities & Most of the time $=2$ \\
\hline & & (like visiting friends, relatives, etc.)? & Some of the time $=3$ \\
\hline & & & A little of the time $=4$ \\
\hline & & & None of the time $=5$ \\
\hline & FI-J & Less outdoor activity; & a \\
\hline & FI-J & Fewer hobbies or interests; & a \\
\hline & EFIPA & Are there activities that someone else has taken over for you recently? & Most of the time; \\
\hline & & & Sometimes; \\
\hline & & & Rarely. \\
\hline & EFIPA & Are there enough organized activities for you nearby? & Most of the time; \\
\hline & & & Sometimes; \\
\hline & & & Rarely. \\
\hline & EFIPA & Do you have problems getting out for organized activities (e.g., & Most of the time; \\
\hline & & problems with transportation to get to them)? & Sometimes; \\
\hline & & & Rarely. \\
\hline & $\mathrm{CMF}$ & Frequency of attending social activities; & Frequency less than weekly. \\
\hline & KCL & Do you go out at least once a week? & Yes; \\
\hline & & & No. \\
\hline & KCL & Do you go out less frequently compared to last year? & Yes; \\
\hline & & & No. \\
\hline & QSFS & Do you go out less frequently compared with last year? & Yes; \\
\hline & & & No. \\
\hline & iRHCFS & Decline in social activities; & Yes; \\
\hline & & & No. \\
\hline
\end{tabular}


Table 2 (continued)

\begin{tabular}{|c|c|c|c|}
\hline Domains & Assessment Tool & Questions & Answers \\
\hline \multirow{38}{*}{ Social network } & \multirow[t]{2}{*}{ iRHCFS } & \multirow[t]{2}{*}{ Reduced social activities; } & Yes; \\
\hline & & & No. \\
\hline & \multirow[t]{2}{*}{ iRHCFS } & \multirow[t]{2}{*}{ Withdrawal from activities of interest; } & Yes; \\
\hline & & & No. \\
\hline & SFI & \multirow{6}{*}{$\begin{array}{l}\text { Infrequent social activities: assessed through a series of questions on } \\
\text { the number and frequencies of usual participation on } 6 \text { categories of } \\
\text { social activities using a 3-point Likert scale; } \\
\text { During the past } 4 \text { weeks, to what extent has your physical health or } \\
\text { emotional problems interfered with your normal social activities with } \\
\text { family, friends, neighbours, or groups? }\end{array}$} & $\begin{array}{l}\text { Participants that rarely or do not at all participate in all } \\
\text { categories of social activities are considered to have this risk } \\
\text { indicator. }\end{array}$ \\
\hline & \multirow[t]{5}{*}{$\mathrm{FI}(4)$} & & Extremely $=5$ \\
\hline & & & Quite a bit $=4$ \\
\hline & & & Moderately $=3$ \\
\hline & & & Slightly $=2$ \\
\hline & & & Not at all $=1$ \\
\hline & \multirow[t]{2}{*}{ FI (5) } & \multirow{2}{*}{$\begin{array}{l}\text { Daily contact with other people through meetings, phone contacts, } \\
\text { emails, etc.; }\end{array}$} & Presence; \\
\hline & & & Absence. \\
\hline & FI-J & Less contact with neighbours; & a \\
\hline & FI-J & Less friendships other than neighbours; & a \\
\hline & CFAI & $\begin{array}{l}\text { Suppose you are unable to carry out the activities you usually do in } \\
\text { the housekeeping for a certain while, whom would you be able to } \\
\text { appeal to? }\end{array}$ & $\begin{array}{l}\text { Social Network } 1 \text { (partner, son and daughter-in-law); } \\
\text { Social Network } 2 \text { (daughter, son-in-law and grandchildren); } \\
\text { Social Network } 3 \text { (brother or sister (-in-law), family, } \\
\text { neighbours and friends). }\end{array}$ \\
\hline & \multirow[t]{5}{*}{ SFP } & \multirow{5}{*}{$\begin{array}{l}\text { How often do you meet or talk to your closest relatives? (less than } \\
\text { once a week) }\end{array}$} & Every day; \\
\hline & & & Every 2 or 3 days; \\
\hline & & & Weekly; \\
\hline & & & Monthly; \\
\hline & & & Once a year. \\
\hline & \multirow[t]{5}{*}{ SFP } & \multirow{5}{*}{$\begin{array}{l}\text { How often do you meet or talk to your friends and/or neighbours? } \\
\text { (less than once a week) }\end{array}$} & Every day; \\
\hline & & & Every 2 or 3 days; \\
\hline & & & Weekly; \\
\hline & & & Monthly; \\
\hline & & & Once a year. \\
\hline & First Step & \multirow[t]{4}{*}{ Social network; } & Sufficient and strong social network ; \\
\hline & \multirow[t]{3}{*}{ Easycare-TOS } & & Large but weak social network; \\
\hline & & & Small but strong social network; \\
\hline & & & Small and weak or no social network. \\
\hline & \multirow[t]{2}{*}{ KCL } & Do you sometimes visit your friends? & Yes; \\
\hline & & & No. \\
\hline & QSFS & Do you sometimes visit your friends? & Yes; \\
\hline & & & No. \\
\hline & QSFS & Do you talk with someone every day? & Yes; \\
\hline & & & No. \\
\hline & SFI & $\begin{array}{l}\text { Infrequent contact: } 3 \text { questions enquiring the frequency of visits or } \\
\text { calls by the individual's family, friends, or loved ones, and perceived }\end{array}$ & $\begin{array}{l}\text { Presence of any one or more of none or no more than once a } \\
\text { year visits from family, friends, or loved ones; }\end{array}$ \\
\hline & & extent of help that can be obtained in their time of need & $\begin{array}{l}\text { None or no more than once a year calls from family, friends, } \\
\text { or loved ones; }\end{array}$ \\
\hline & & & None to a very little extent of help when they require it. \\
\hline Loneliness & PSQ & Are you confined to your home through ill health? & Yes; \\
\hline & & & No. \\
\hline & FI(1) & Loneliness all the time; & All the time; \\
\hline & & & Sometimes; \\
\hline & & & Never. \\
\hline & $\mathrm{FI}(2)$ & Feels lonely; & Does not feel lonely; \\
\hline & & & Feels lonely. \\
\hline & $\mathrm{FI}(2)$ & Social Isolation; & $\begin{array}{l}\text { Never or hardly ever alone, or for about one hour, during the } \\
\text { day; }\end{array}$ \\
\hline & & & Alone for long periods of time or all the time. \\
\hline & FI(5) & Do you feel lonely? & Presence; \\
\hline & & & Absence. \\
\hline & EFIPA & Do you feel lonely? & Most of the time; \\
\hline & & & Sometimes; \\
\hline & & & Rarely. \\
\hline & GFI & Do you sometimes feel abandoned? & Yes; \\
\hline & & & No. \\
\hline & GFI & Do you sometimes experience emptiness around yourself? & Yes; \\
\hline & & & No. \\
\hline & GFI & Do you sometimes miss people around yourself? & Yes; \\
\hline & & & No. \\
\hline
\end{tabular}


Table 2 (continued)

\begin{tabular}{|c|c|c|c|}
\hline Domains & Assessment Tool & Questions & Answers \\
\hline & TFI & Do you sometimes miss having people around you? & Yes; \\
\hline & & & No; \\
\hline & & & Sometimes. \\
\hline & First Step & Loneliness; & No loneliness; \\
\hline & Easycare-TOS & & $\begin{array}{l}\text { Had complaints of loneliness in the past } 12 \text { months; } \\
\text { Unknown. }\end{array}$ \\
\hline \multirow[t]{22}{*}{ Living alone } & PSQ & Do you live on your own? & Yes; \\
\hline & & & No. \\
\hline & SPQ & Do you live alone? & Yes; \\
\hline & & & No. \\
\hline & FI (6) & Lives alone; & Yes; \\
\hline & & & No. \\
\hline & FI-CGA & Living alone; & Institutionalized; \\
\hline & & & Uses formal home supports; \\
\hline & & & Living alone. \\
\hline & TFI & Do you live alone? & Yes; \\
\hline & & & No. \\
\hline & SFP & Living alone; & Yes; \\
\hline & & & No. \\
\hline & GFST & Does your patient live alone? & Yes; \\
\hline & & & No; \\
\hline & & & Don't Know. \\
\hline & $\mathrm{CMF}$ & Living alone; & Living alone; \\
\hline & & & Living with family. \\
\hline & QSFS & Do you live alone? & Yes; \\
\hline & & & No. \\
\hline & SFI & Who do you live with? & Alone; \\
\hline & & & With others. \\
\hline \multirow[t]{17}{*}{ Socio-demographic } & FI (6) & Marital status; & $\begin{array}{l}\text { Yes }=0 \\
\text { No }=1\end{array}$ \\
\hline & FI (6) & Family's money situation; & Bad; \\
\hline & & & Good. \\
\hline & VES-13 & Age; & 0 -age 65-74; \\
\hline & & & 1-age 75-84; \\
\hline & & & 3age $\geq 85$ \\
\hline & Prisma-7 & Are you older than 85 years? & Yes; \\
\hline & & & No. \\
\hline & Prisma-7 & Are you male? & Yes; \\
\hline & & & No. \\
\hline & SFI & What is your education level? & Nil; \\
\hline & & & Primary; \\
\hline & & & Secondary or Institute of Technical Education; \\
\hline & & & Pre-University or Polytechnic; \\
\hline & & & University. \\
\hline & SFI & $\begin{array}{l}\text { Are you limited by your financial resources to pay for needed medical } \\
\text { service? }\end{array}$ & $\begin{array}{l}\text { Present for participants who indicate that they were limited } \\
\text { "to a great extent". }\end{array}$ \\
\hline & SFI & $\begin{array}{l}\text { Socioeconomic deprivation: assessed by proxy of the participant's } \\
\text { housing type }\end{array}$ & Participants who lived in "1- to 2-room flats". \\
\hline \multirow[t]{12}{*}{ Lifestyle } & FI(3) & Smoking and drinking; & Yes; \\
\hline & & & Occasionally; \\
\hline & & & No. \\
\hline & $\mathrm{FI}(3)$ & Physical exercise; & Yes; \\
\hline & & & Occasionally; \\
\hline & & & No. \\
\hline & FI(3) & Sleep quality; & Poor quality; \\
\hline & & & Good Quality. \\
\hline & FRAGIRE & Do you participate in sport activities (sports, art, etc)? & Not at all; \\
\hline & & & A little; \\
\hline & & & Quite a bit; \\
\hline & & & Very much. \\
\hline \multirow[t]{9}{*}{ Work } & $\mathrm{FI}(1)$ & Work limitations; & Major limitation; \\
\hline & & & Minor limitation; \\
\hline & & & No limitation. \\
\hline & $\mathrm{FI}(3)$ & Work performing; & Yes; \\
\hline & & & Occasionally; \\
\hline & & & No. \\
\hline & $\mathrm{FI}(3)$ & Doing housework; & Yes; \\
\hline & & & Occasionally; \\
\hline & & & No. \\
\hline
\end{tabular}


Table 2 (continued)

\begin{tabular}{|c|c|c|c|}
\hline Domains & Assessment Tool & Questions & Answers \\
\hline \multirow[t]{2}{*}{ Social context } & EFIPA & Do you have any housing problems? & $\begin{array}{l}\text { Most of the time; } \\
\text { Sometimes; } \\
\text { Rarely. }\end{array}$ \\
\hline & $\begin{array}{l}\text { Second Step } \\
\text { Easycare-TOS }\end{array}$ & $\begin{array}{l}\text { How do you evaluate the following domains in this patient? (Covers: } \\
\text { safety, environment, social network/loneliness, social activities) }\end{array}$ & $\begin{array}{l}\text { Good; } \\
\text { Fair; } \\
\text { Poor. }\end{array}$ \\
\hline Cultural & FRAGIRE & Do you use internet? & $\begin{array}{l}\text { Not at all; } \\
\text { A little; } \\
\text { Quite a bit; } \\
\text { Very much. }\end{array}$ \\
\hline Social role & QSFS & Do you feel you are helpful to friends or family? & $\begin{array}{l}\text { Yes; } \\
\text { No. }\end{array}$ \\
\hline
\end{tabular}

\footnotetext{
a English translation not available.
}

depressive symptomatology, social isolation and feelings of loneliness are progressively higher when frailty increases among different groups: robust, pre-frail and frail (Mulasso, Roppolo, Giannota, \& Rabaglietti, 2016). Loneliness is associated with frailty (Gale, Westbury, \& Cooper, 2017; Herrera-Badilla, Navarrete-Reyes, Amieva, \& Avila-Funes, 2015) and poor social functioning (Hoogendijk et al., 2016). People living alone, including those who are frail, have a lower availability of personal care and greater social and financial vulnerability (Bilotta et al., 2010). Some tools use social isolation and others loneliness as social components. It is known that both concepts have a relationship with frailty, but new studies would be necessary to understand and to distinguish which one best evaluates frailty.

Regarding to social activities, such as gatherings, leisure activities and religious activities, visiting friends and family and talking with neighbours, these have shown to be associated with a lower probability of frailty (Chen et al., 2014); but none of the instruments included in this review specifies the type of social activities under assessment, reporting an overall set of behaviours. We point out that cultural factors and cross-cultural differences, such the religious activities, may also have an impact on the social dimensions of frailty, by building social networks (Lim \& Putnam, 2010) and increasing social support (Roh et al., 2015). However more studies would be necessary to explore this relationship.

As a component of frailty, work has found to have little expressiveness in the instruments considered in this review. Future studies should explore relationship between work and frailty, being particularly relevant to distinguish different types of work that can be carried out by the older population. A recent study has shown that volunteering is associated with a lower cumulative probability of frailty, being a more significant predictor than paid work or taking care of children (Jung, Gruenewald, Seeman, \& Sarkisian, 2010). Allied to work, the feeling of usefulness towards friends and family may refer to its social role, but it appears in a single instrument under review. It has been documented the existence of a relationship between social role and frailty (Makizako et al., 2015) and that it can influence the social network of contacts (Hlebec, Mrzel, \& Kogovšek, 2009) as well as to predict significantly the future onset of disability in instrumental activities of daily living (Fujiwara et al., 2003). However, there is a shortage of studies sustaining this association.

Finally, it seems to be consensual in the literature the insertion of lifestyle items such as smoking, drinking and physical inactivity as belonging to the social domain and its relation with the increase of frailty (de Labra, Guimaraes-Pinheiro, Maseda, Lorenzo, \& MillánCalenti, 2015; Etman, Kamphuis, Van Der Cammen, Burdorf, \& Van Lenthe, 2015; Kojima, Iliffe, \& Walters, 2015; Ortolá et al., 2015; Peterson et al., 2009; van Oostrom et al., 2017; Woo, Goggins, Sham, \& Ho, 2005, 2015). A recent study indicates that a general self-report question about lifestyle (e.g., "Overall, how healthy would you say your lifestyle is?") is preferable than enumerating a list of factors, being sufficient to predict frailty (Gobbens \& van Assen, 2016). The lack of consensus on lifestyle items that may arise as determinants or as components of frailty suggests the need to rethink the relationship of lifestyle with frailty as well as its way of inquiry in future studies.

For the future, we advocate the creation of a definition and operationalization of social frailty internationally capable of being translated into a new tool in order to add predictive power to any assessment of frailty (Berrut et al., 2013; Buta et al., 2016; Dent et al., 2016). It is also suggested the longitudinal study of the social components listed in this review in the prediction of frailty and adverse outcomes. Previous longitudinal studies showed that social frailty predicted few adverse outcomes and that the physical dimension was the most important predictor (Coelho, Paúl, Gobbens, \& Fernandes, 2015; Gobbens \& van Assen, 2012; Gobbens, Van Assen, Luijkx, \& Schols, 2012). However, the accumulation of social deficits was associated with significant increases in mortality risk (Armstrong et al., 2015), disability risk (Teo et al., 2017) and the social frailty phenotype was able to predict the risk of mortality almost as much as physical frailty in the study of GarreOlmo et al. (2013). Recently, the study of Makizako et al. (2018) reports that social frailty may precede and lead to the development of physical frailty.

As strengths of the present study, it is important to highlight the identification, organization and systematization of the different social components most frequently used by different frailty assessment tools. It is estimated that in collecting these components, this study contributes to the understanding and convergence of a definition of multidimensional frailty as a complex and dynamic system between social, biological and psychological factors. As limitations it can be indicated that this review has been restricted exclusively to a single database, to the English language and the exclusion of studies where frailty was not a main term, because there may be studies that relate social factors to synonyms of frailty. Thus, there may be different operationalisations of the concept in a population that has not been defined as frail. It should also be stressed that the inclusion of modified versions of the assessment tools could result in an increase of identified social factors.

In general, the number of multidimensional assessment tools found in this review study reflects the lack of consensus on the concept of frailty and its assessment in the last 17 years. Social components of frailty vary from instrument to instrument and cover the concepts of social isolation, loneliness, social network, social support and social participation. However, the factors that constitute social frailty should be mirrored in clear and concrete questions concerning what is in fact intended to assess. In this sense, it is important that future studies identify which social components of frailty contribute the most to define a state of increased vulnerability and a greater risk of adverse outcomes. 


\section{References}

Aguayo, G. A., Donneau, A. F., Vaillant, M. T., Schritz, A., Franco, O. H., Stranges, S., et al. (2017). Agreement between 35 published frailty scores in the general population. American Journal of Epidemiology, 186(4), 420-434. http://dx.doi.org/10.1093/aje/ kwx061.

Alvarado, B. E., Zunzunegui, M. V., Beland, F., \& Bamvita, J. M. (2008). Life course social and health conditions linked to frailty in Latin American older men and women. The Journals of Gerontology. Series A, Biological Sciences and Medical Sciences, 63(12), 1399-1406.

Arai, H., \& Satake, S. (2015). English translation of the Kihon Checklist. Geriatrics and Gerontology International, 15(4), 518-519. http://dx.doi.org/10.1111/ggi.12397.

Armstrong, J. J., Andrew, M. K., Mitnitski, A., Launer, L. J., White, L. R., \& Rockwood, K. (2015). Social vulnerability and survival across levels of frailty in the Honolulu-Asia aging study. Age and Ageing, 44(4), 709-712. http://dx.doi.org/10.1093/ageing/ afv016.

Bäckman, K., Joas, E., Falk, H., Mitnitski, A., Rockwood, K., \& Skoog, I. (2017). Changes in the lethality of frailty over 30 years: evidence from two cohorts of 70-year-olds in Gothenburg Sweden. Journals of Gerontology - Series A Biological Sciences and Medical Sciences, 72(7), 945-950. http://dx.doi.org/10.1093/gerona/glw160.

Barber, J. H., Wallis, J. B., \& McKeating, E. (1980). A postal screening questionnaire in preventive geriatric care. The Journal of the Royal College of General Practitioners, 30(210), 49-51. Retrieved from http://www.ncbi.nlm.nih.gov/pubmed/ 7373578\%5Cnhttp://www.pubmedcentral.nih.gov/articlerender.fcgi?artid = PMC2159402.

Berrut, G., Andrie, S., De Carvalho, I. A., Bayeyens, J. P., Bergman, H., Cassim, B., et al. (2013). Promoting access to innovation for frail old persons. IAGG (International Association of Gerontology and Geriatrics), WHO (World Health Organization) and SFGG (Société Française de Gériatrie et de Gérontologie) Workshop-Athens January 20-21, 2012 Journal of Nutrition, Health and Aging, 17(8), 688-693.

Bilotta, C., Casè, A., Nicolini, P., Mauri, S., Castelli, M., \& Vergani, C. (2010). Social vulnerability, mental health and correlates of frailty in older outpatients living alone in the community in Italy. Aging \& Mental Health, 14(8), 1024-1036. http://dx.doi. org/10.1080/13607863.2010.508772.

Bouillon, K., Kivimaki, M., Hamer, M., Sabia, S., Fransson, E. I., Singh-Manoux, A., et al. (2013). Measures of frailty in population-based studies: An overview. BMC Geriatrics, 13(1), 1. http://dx.doi.org/10.1186/1471-2318-13-64.

Buckinx, F., Rolland, Y., Reginster, J. Y., Ricour, C., Petermans, J., \& Bruyère, O. (2015). Burden of frailty in the elderly population: Perspectives for a public health challenge. Archives of Public Health = Archives Belges de Santé Publique, 73(1), 19. http://dx.doi. org/10.1186/s13690-015-0068-X.

Bunt, S., Steverink, N., Olthof, J., Schans, C., \& Hobbelen, J. (2017). Social frailty in older adults : A scoping review. European Journal of Ageing, 14(3), 323-334. http://dx.doi. org/10.1007/s10433-017-0414-7.

Buta, B. J., Walston, J. D., Godino, J. G., Park, M., Kalyani, R. R., Xue, Q., et al. (2016). Frailty assessment instruments : Systematic characterization of the uses and contexts of highly-cited instruments. Ageing Research Reviews, 26, 53-61. http://dx.doi.org/ 10.1016/j.arr.2015.12.003.

Cacciatore, F., Abete, P., Mazzella, F., Viati, L., Della Morte, D., D’Ambrosio, D., et al. (2005). Frailty predicts long-term mortality in elderly subjects with chronic heart failure. European Journal of Clinical Investigation, 35, 723-730. http://dx.doi.org/10. 1111/j.1365-2362.2005.01572.x.

Cesari, M., Gambassi, G., Van Kan, G., \& Vellas, B. (2014). The frailty phenotype and the frailty index: Different instruments for different purposes. Age and Ageing, 43(1), 10-12. http://dx.doi.org/10.1093/ageing/aft160.

Cesari, M., Prince, M., Thiyagarajan, J., De Carvalho, I., Bernabei, R., Chan, P., et al. (2016). Frailty: An emerging public health priority. Journal of the American Medica Directors Association, 1-5. http://dx.doi.org/10.1016/j.jamda.2015.12.016.

Chen, L. J., Chen, C. Y., Lue, B. H., Tseng, M. Y., \& Wu, S. C. (2014). Prevalence and associated factors of frailty among elderly people in Taiwan. International Journal of Gerontology, 8(3), 114-119. http://dx.doi.org/10.1016/j.ijge.2013.12.002.

Clegg, A., Young, J., Iliffe, S., Rikkert, M. O., \& Rockwood, K. (2013). Frailty in elderly people. The Lancet, 381(9868), 752-762. http://dx.doi.org/10.1016/S0140-6736(12) 62167-9.

Coelho, T. (2015). Modelo integral de fragilidade do idoso (do constructo à avaliação - Tilburg frailty indicator)(doctoral dissertation). Porto: University of Porto and University of Aveiro.

Coelho, T., Paúl, C., Gobbens, R. J. J., \& Fernandes, L. (2015). Frailty as a predictor of short-term adverse outcomes. PeerJ, 3, e1121. http://dx.doi.org/10.7717/peerj. 1121.

Collard, R. M., Boter, H., Schoevers, R. A., \& Oude Voshaar, R. C. (2012). Prevalence of frailty in community-dwelling older persons: A systematic review. Journal of the American Geriatrics Society, 60(8), 1487-1492. http://dx.doi.org/10.1111/j.1532 5415.2012.04054.x

de Labra, C., Guimaraes-Pinheiro, C., Maseda, A., Lorenzo, T., \& Millán-Calenti, J. C.
(2015). Effects of physical exercise interventions in frail older adults: A systematic review of randomized controlled trials. BMC Geriatrics, 15, 154. http://dx.doi.org/10 1186/s12877-015-0155-4

de Labra, C., Maseda, A., Lorenzo-López, L., López-López, R., Buján, A., RodríguezVillamil, J. L., et al. (2018). Social factors and quality of life aspects on frailty syndrome in community-dwelling older adults: The VERISAÚDE study. BMC Geriatrics, 18(1), 1-9. http://dx.doi.org/10.1186/s12877-018-0757-8.

de Vries, N. M., Staal, J. B., Olde Rikkert, M. G. M., \& Nijhuis-van der Sanden, M. W. G. (2013). Evaluative frailty index for physical activity (EFIP): A reliable and valid instrument to measure changes in level of frailty. Physical Therapy, 93(4), 551-561. http://dx.doi.org/10.2522/ptj.20120127.

de Vries, N. M., Staal, J. B., van Ravensberg, C. D., Hobbelen, J. S. M., Olde Rikkert, M. G. M., \& Nijhuis-van der Sanden, M. W. G. (2011). Outcome instruments to measure frailty: A systematic review. Ageing Research Reviews, 10(1), 104-114. http://dx.doi. org/10.1016/j.arr.2010.09.001.

De Witte, N., Gobbens, R., De Donder, L., Dury, S., Buffel, T., Schols, J., et al. (2013a). The comprehensive frailty assessment instrument: Development, validity and reliability. Geriatric Nursing, 34(4), 274-281. http://dx.doi.org/10.1016/j.gerinurse.2013.03. 002.

De Witte, N., Gobbens, R., De Donder, L., Dury, S., Buffel, T., Verté, D., et al. (2013b) Validation of the comprehensive frailty assessment instrument against the Tilburg frailty indicator. European Geriatric Medicine, 4(4), 248-254. http://dx.doi.org/10. 1016/j.eurger.2013.03.001.

Dent, E., Dal Grande, E., Price, K., \& Taylor, A. W. (2017). Frailty and usage of health care systems: Results from the South Australian Monitoring and Surveillance System (SAMSS). Maturitas, 104, 36-43. http://dx.doi.org/10.1016/j.maturitas.2017.07. 003.

Dent, E., Kowal, P., \& Hoogendijk, E. O. (2016). Frailty measurement in research and clinical practice: A review. European Journal of Internal Medicine, 31, 3-10. http://dx. doi.org/10.1016/j.ejim.2016.03.007.

Duarte, M., Fernandes, M., Rodrigues, R., \& Nóbrega, M. (2013). Prevalência e fatores sociodemográficos associados à fragilidade em mulheres idosas. Revista Brasileira de Enfermagem, 66(6), 901-906.

Etman, A., Burdorf, A., Van der Cammen, T., Mackenbach, J., \& Van Lenthe, F. (2012). Socio-demographic determinants of worsening in frailty among community-dwelling older people in 11 European countries. Journal of Epidemiology and Community Health, 66(12), 1116-1121. http://dx.doi.org/10.1136/jech-2011-200027.

Etman, A., Kamphuis, C., Van Der Cammen, T., Burdorf, A., \& Van Lenthe, F. (2015). Do lifestyle, health and social participation mediate educational inequalities in frailty worsening? European Journal of Public Health, 25(2), 345-350. http://dx.doi.org/10. 1093/eurpub/cku093.

Fried, L. P., Tangen, C. M., Walston, J., Newman, A. B., Hirsch, C., Gottdiener, J., et al. (2001). Frailty in older adults: Evidence for a phenotype. Journals of Gerontology Series a-Biological Sciences and Medical Sciences, 56(3), M146-M156. http://dx.doi. org/10.1093/gerona/56.3.M146.

Fujiwara, Y., Shinkai, S., Kumagai, S., Amano, H., Yoshida, Y., Yoshida, H., et al. (2003). Longitudinal changes in higher-level functional capacity of an older population living in a Japanese urban community. Archives of Gerontology and Geriatrics, 36(2), 141-153. http://dx.doi.org/10.1016/S0167-4943(02)00081-X.

Fukutomi, E., Okumiya, K., Wada, T., Sakamoto, R., Ishimoto, Y., Kimura, Y., et al. (2015). Relationships between each category of 25-item frailty risk assessment (Kihon Checklist) and newly certified older adults under long-term care insurance: A 24-month follow-up study in a rural community in Japan. Geriatrics \& Gerontology International, 15, 864-871. http://dx.doi.org/10.1111/ggi.12360.

Gale, C. R., Westbury, L., \& Cooper, C. (2017). Social isolation and loneliness as risk factors for the progression of frailty: The English longitudinal study of ageing. Age and Ageing, (May), 392-397. http://dx.doi.org/10.1093/ageing/afx188.

Garre-Olmo, J., Calvó-Perxas, L., López-Pousa, S., De Gracia Blanco, M., \& Vilalta-Franch, J. (2013). Prevalence of frailty phenotypes and risk of mortality in a communitydwelling elderly cohort. Age and Ageing, 42(1), 46-51. http://dx.doi.org/10.1093/ ageing/afs047.

Gobbens, R. J., \& van Assen, M. A. L. M. (2012). Frailty and its prediction of disability and health care utilization: The added value of interviews and physical measures following a self-report questionnaire. Archives of Gerontology and Geriatrics, 55(2), 369-379. http://dx.doi.org/10.1016/j.archger.2012.04.008.

Gobbens, R., \& van Assen, M. (2016). Explaining frailty by lifestyle. Archives of Gerontology and Geriatrics, 66, 49-53. http://dx.doi.org/10.1016/j.archger.2016.04. 011.

Gobbens, R. J. J., Van Assen, M. A. L. M., Luijkx, K. G., \& Schols, J. M. G. A. (2012). The predictive validity of the tilburg frailty indicator: Disability, health care utilization, and quality of life in a population at risk. Gerontologist, 52(5), 619-631. http://dx.doi. org/10.1093/geront/gnr135.

Gobbens, R., Luijkx, K., Wijnen-Sponselee, M., \& Schols, J. (2010). Toward a conceptual definition of frail community dwelling older people. Nursing Outlook, 58(2), 76-86. http://dx.doi.org/10.1016/j.outlook.2009.09.005.

Gobbens, R., van Assen, M., Luijkx, K., Wijnen-Sponselee, M., \& Schols, J. (2010). The tilburg frailty indicator: Psychometric properties. Journal of the American Medical Directors Association, 11(5), 344-355. http://dx.doi.org/10.1016/j.jamda.2009.11. 003.

Guessous, I., Luthi, J. C., Bowling, C. B., Theler, J. M., Paccaud, F., Gaspoz, J. M., et al. (2014). Prevalence of frailty indicators and association with socioeconomic status in middle-aged and older adults in a swiss region with universal health insurance coverage: A population-based cross-sectional study. Journal of Aging Research, 2014. http://dx.doi.org/10.1155/2014/198603.

Haber, M. G., Cohen, J. L., Lucas, T., \& Baltes, B. B. (2007). The relationship between selfreported received and perceived social support: A meta-analytic review. American 
Journal of Community Psychology, 39(1-2), 133-144. http://dx.doi.org/10.1007/ s10464-007-9100-9.

Hawkley, L. C. (2015). Loneliness and social embeddedness in old age louise. Encyclopedia of Geropsychology, 1-8. http://dx.doi.org/10.1007/978-981-287-080-3.

Hebert, R., Bravo, G., Korner-Bitensky, N., \& Voyer, L. (1996). Predictive validity of a postal questionnaire for screening community- dwelling elderly individuals at risk of functional decline. Age and Ageing, 25(2), 159.

Hébert, R., Durand, P. J. P., Dubuc, N., \& Tourigny, A. (2003). Frail elderly patients. New model for integrated service delivery. Canadian Family Physician Médecin de Famille Canadien, 49, 992-997. Retrieved from http://www.pubmedcentral.nih.gov/ articlerender.fcgi artid $=2214268 \&$ tool $=$ pmcentrez\&rendertype $=$ abstract \%0Ahttp://www.cfp.ca/content/49/8/992.short.

Herr, M., Robine, J. M., Aegerter, P., Arvieu, J. J., \& Ankri, J. (2015). Contribution of socioeconomic position over life to frailty differences in old age: Comparison of lifecourse models in a French sample of 2350 old people. Annals of Epidemiology, 25(9), 674-680. http://dx.doi.org/10.1016/j.annepidem.2015.05.006.

Herrera-Badilla, A., Navarrete-Reyes, A. P., Amieva, H., \& Avila-Funes, J. A. (2015), Loneliness is associated with frailty in community-dwelling elderly adults. Journal of the American Geriatrics Society, 63(3), 607-609.

Hlebec, V., Mrzel, M., \& Kogovšek, T. (2009). Social support network and received support at stressful events. Advances in Methodology \& Statistics / Metodološki Zvezki, 5(1), 155-171.

Hogan, D. B., MacKnight, C., Bergman, H., \& Steering Committee (2003). Models, definitions, and criteria of frailty. C. I. on F. and A. Aging Clinical and Experimental Research, 15(3), 3-29. http://dx.doi.org/10.1016/B978-012369391-4/50051-5.

Hoogendijk, E., Suanet, B., Dent, E., Deeg, D., \& Aartsen, M. (2016). Adverse effects of frailty on social functioning in older adults: Results from the longitudinal aging study Amsterdam. Maturitas, 83, 45-50. http://dx.doi.org/10.1016/j.maturitas.2015.09. 002 .

Jones, D., Song, X., Mitnitski, A., \& Rockwood, K. (2005). Evaluation of a frailty index based on a comprehensive geriatric assessment in a population based study of elderly Canadians. Aging Clinical and Experimental Research, 17(6), 465-471. http://dx.doi. org/10.1007/BF03327413.

Jung, Y., Gruenewald, T. L., Seeman, T. E., \& Sarkisian, C. A. (2010). Productive activities and development of frailty in older adults. Journals of Gerontology - Series B Psychological Sciences and Social Sciences, 65 B(2), 256-261. http://dx.doi.org/10. 1093/geronb/gbp105.

Karunananthan, S., Wolfson, C., Bergman, H., Béland, F., \& Hogan, D. (2009). A multidisciplinary systematic literature review on frailty: Overview of the methodology used by the Canadian initiative on frailty and aging. BMC Medical Research Methodology, 9, 68. http://dx.doi.org/10.1186/1471-2288-9-68.

Kojima, G., Iliffe, S., \& Walters, K. (2015). Smoking as a predictor of frailty: A systematic review. BMC Geriatrics, 15, 131. http://dx.doi.org/10.1186/s12877-015-0134-9.

Kwan, J. S. K., Lau, B. H. P., \& Cheung, K. S. L. (2015). Toward a comprehensive model of frailty: An emerging concept from the Hong Kong centenarian study. Journal of the American Medical Directors Association, 16(6), http://dx.doi.org/10.1016/j.jamda. 2015.03.005 536.e1-536.e7

Lachs, M., Feinstein, A., Cooney, L., Drickamer, M., Marottoli, R., Pannill, F., et al. (1990). A simple procedure for general screening for functional disability in elderly patients. Annals of Internal Medicine. http://dx.doi.org/10.7326/0003-4819-112-9-699.

Lim, C., \& Putnam, R. (2010). Religion, social networks, and life satisfaction. American Sociological Review, 75(6), 914-933. http://dx.doi.org/10.1177/0003122410386686.

Ma, L., Zhang, L., Tang, Z., Sun, F., Diao, L., Wang, J., et al. (2016). Use of the frailty index in evaluating the prognosis of older people in Beijing: A cohort study with an 8year follow-up. Archives of Gerontology and Geriatrics, 64, 172-177. http://dx.doi.org/ 10.1016/j.archger.2015.11.002.

Makizako, H., Shimada, H., Doi, T., Tsutsumimoto, K., Hotta, R., Nakakubo, S., et al. (2018). Social frailty leads to the development of physical frailty among physically non-frail adults: A four-year follow-up longitudinal cohort study. International Journal of Environmental Research and Public Health, 15(3), http://dx.doi.org/10.3390/ ijerph15030490.

Makizako, H., Shimada, H., Tsutsumimoto, K., Lee, S., Doi, T., Nakakubo, S., et al. (2015). Social frailty in community-dwelling older adults as a risk factor for disability. Journal of the American Medical Directors Association, 16(11), http://dx.doi.org/10. 1016/j.jamda.2015.08.023 1003.e7-1003.e11.

Markle-Reid, M., \& Browne, G. (2003). Conceptualizations of frailty in relation to older adults. Journal of Advanced Nursing, 44(1), 58-68. http://dx.doi.org/10.1046/j.13652648.2003.02767.x.

McKenzie, K., Ouellette-Kuntz, H., \& Martin, L. (2015). Using an accumulation of deficits approach to measure frailty in a population of home care users with intellectual and developmental disabilities: an analytical descriptive study. BMC Geriatrics, 15, 170-183. http://dx.doi.org/10.1186/s12877-015-0170-5.

Mitnitski, A. B., Mogilner, A. J., \& Rockwood, K. (2001). Accumulation of deficits as a proxy measure of aging. The Scientific World JOURNAL, 1, 323-336. http://dx.doi. org/10.1100/tsw.2001.58.

Mohandas, A., Reifsnyder, J., Jacobs, M., \& Fox, T. (2011). Current and future directions in frailty research. Population Health Management, 14(6), 277-283. http://dx.doi.org/ 10.1089/pop.2010.0066

Morris, J. N., Howard, E. P., \& Steel, K. R. (2016). Development of the interRAI home care frailty scale. BMC Geriatrics, 16(1), 1-9. http://dx.doi.org/10.1186/s12877-0160364-5.

Moser, A., Stuck, A. E., Silliman, R. A., Ganz, P. A., \& Clough-Gorr, K. M. (2012). The eight-item modified medical outcomes study social support survey: Psychometric evaluation showed excellent performance. Journal of Clinical Epidemiology, 65(10), 1107-1116. http://dx.doi.org/10.1016/j.jclinepi.2012.04.007.

Mulasso, A., Roppolo, M., Giannota, F., \& Rabaglietti, E. (2016). Associations of frailty and psychosocial factors with autonomy in daily activities : A cross-sectional study in Italian community-dwelling older adults. Clinical Interventions in Aging, 11, 37-45.

Myers, V., Drory, Y., Goldbourt, U., \& Gerber, Y. (2014). Multilevel socioeconomic status and incidence of frailty post myocardial infarction. International Journal of Cardiology, 170(3), 338-343. http://dx.doi.org/10.1016/j.ijcard.2013.11.009.

Niti, M., Yap, K. B., Kua, E. H., Tan, C. H., \& Ng, T. P. (2008). Physical, social and productive leisure activities, cognitive decline and interaction with APOE- 4 genotype in Chinese older adults. International Psychogeriatrics, 20(2), 237-251. http://dx.doi. org/10.1017/S1041610207006655.

Op Het Veld, L., van Rossum, E., Kempen, G., de Vet, H., Hajema, K., \& Beurskens, A. (2015). Fried phenotype of frailty: Cross-sectional comparison of three frailty stages on various health domains. BMC Geriatrics, 15, 77. http://dx.doi.org/10.1186/ s12877-015-0078-0.

Ortolá, R., García-Esquinas, E., León-Muñoz, L., Guallar-Castillón, P., Valencia-Martín, J., Galán, I., et al. (2015). Patterns of alcohol consumption and risk of frailty in community-dwelling older adults. The Journals of Gerontology Series A: Biological Sciences and Medical Sciences, 71(2), 251-258. http://dx.doi.org/10.1093/gerona/glv125.

Peterson, M. J., Giuliani, C., Morey, M. C., Pieper, C. F., Evenson, K. R., Mercer, V., et al. (2009). Physical activity as a preventative factor for frailty: The health, aging, and body composition study. Journals of Gerontology - Series A Biological Sciences and Medical Sciences, 64(1), 61-68. http://dx.doi.org/10.1093/gerona/gln001.

Raîche, M., Hébert, R., \& Dubois, M. F. (2008). PRISMA-7: A case-finding tool to identify older adults with moderate to severe disabilities. Archives of Gerontology and Geriatrics, 47(1), 9-18. http://dx.doi.org/10.1016/j.archger.2007.06.004.

Rockwood, K., \& Mitnitski, A. (2007). Frailty in relation to the accumulation of deficits. The Journals of Gerontology: Biological Sciences and Medical Sciences, 62(7), 722-727. http://dx.doi.org/10.1093/gerona/62.7.722.

Rodríguez-Mañas, L., Féart, C., Mann, G., Viña, J., Chatterji, S., Chodzko-Zajko, W., et al. (2013). Searching for an operational definition of frailty: A delphi method based consensus statement. The frailty operative definition-consensus conference project. Journals of Gerontology - Series A Biological Sciences and Medical Sciences, 68(1), 62-67. http://dx.doi.org/10.1093/gerona/gls119.

Roh, S., Kim, Y., Lee, K., Lee, Y., Burnette, C., \& Lawler, M. (2015). Religion, social support, and life satisfaction among American Indian older adults. Journal of Religion \& Spirituality in Social Work: Social Thought, 34(4), 414-434. http://dx.doi.org/10. 1080/15426432.2015.1097094.

Rolfson, D. B., Majumdar, S. R., Tsuyuki, R. T., Tahir, A., \& Rockwood, K. (2006). Validity and reliability of the Edmonton frail scale. Age and Ageing, 35(5), 526-529. http://dx. doi.org/10.1093/ageing/afl023.

Roppolo, M., Mulasso, A., Gobbens, R. J., Mosso, C. O., \& Rabaglietti, E. (2015). A comparison between uni- and multidimensional frailty measures: Prevalence, functional status, and relationships with disability. Clinical Interventions in Aging, 10, 1669-1678. http://dx.doi.org/10.2147/CIA.S92328.

Saliba, D., Elliott, M., Rubenstein, L. Z., Solomon, D. H., Young, R. T., Kamberg, C. J. et al. (2001). The vulnerable elders survey: A tool for identifying vulnerable older people in the community. Journal of De American Geriatrics Society, 49(12), 1691-1699. http://dx.doi.org/10.1046/j.1532-5415.2001.49281.x.

Satake, S., Senda, K., Hong, Y. J., Miura, H., Endo, H., Sakurai, T., et al. (2016). Validity of the Kihon Checklist for assessing frailty status. Geriatrics and Gerontology International, 16(6), 709-715. http://dx.doi.org/10.1111/ggi.12543.

Schuurmans, H., Steverink, N., Lindenberg, S., Frieswijk, N., \& Slaets, J. P. J. (2004). Old or frail: What tells us more? The Journals of Gerontology. Series A, Biological Sciences and Medical Sciences, 59(9), M962-5. http://dx.doi.org/10.1093/gerona/59.9.M962.

Searle, S. D., Mitnitski, A., Gahbauer, E. A., Gill, T. M., \& Rockwood, K. (2008). A standard procedure for creating a frailty index. BMC Geriatrics, 8 , 24. http://dx.doi.org/ 10.1186/1471-2318-8-24.

Sherbourne, C. D., \& Stewart, A. L. (1991). The MOS social support survey. Social Science and Medicine, 32(6), 705-714. http://dx.doi.org/10.1016/0277-9536(91)90150-B.

St John, P. D., Montgomery, P. R., \& Tyas, S. L. (2013). Social position and frailty. Canadian Journal on Aging (La Revue Canadienne Du Vieillissement), 32(3), 250-259. http://dx.doi.org/10.1017/S0714980813000329.

Sternberg, S. A., Schwartz, A. W., Karunananthan, S., Bergman, H., \& Clarfield, M. (2011). The identification of frailty: A systematic literature review. Journal of the American Geriatrics Society, 59(11), 2129-2138. http://dx.doi.org/10.1111/j.1532-5415.2011. 03597.x.

Steverink, N., Slaets, J. P. J., Schuurmans, H., \& van Lis, M. (2001). Measuring frailty: Developing and testing the GFI (Groningen frailty indicator). Gerontologist, 41 236-237.

Sutton, J. L., Gould, R. L., Daley, S., Coulson, M. C., Ward, E. V., Butler, A. M., et al. (2016). Psychometric properties of multicomponent tools designed to assess frailty in older adults: A systematic review. BMC Geriatrics, 16(1), 55. http://dx.doi.org/10. 1186/s12877-016-0225-2

Tavassoli, N., Guyonnet, S., Van Kan, G. A., Sourdet, S., Krams, T., Soto, M. E., et al. (2014). Description of 1, 108 older patients referred by their physician to the "Geriatric Frailty clinic (G.F.C) for assessment of Frailty and prevention of disability" at the gerontopole. Journal of Nutrition, Health and Aging, 18(5), 457-464. http://dx. doi.org/10.1007/s12603-014-0462-z.

Teo, N., Gao, Q., Nyunt, M. S. Z., Wee, S. L., \& Ng, T. P. (2017). Social frailty and functional disability: Findings from the Singapore longitudinal ageing studies. Journal of the American Medical Directors Association, 18(7), http://dx.doi.org/10.1016/j. jamda.2017.04.015 637.e13-637.e19.

Theou, O., Brothers, T. D., Mitnitski, A., \& Rockwood, K. (2013). Operationalization of frailty using eight commonly used scales and comparison of their ability to predict all-cause mortality. Journal of the American Geriatrics Society, 61(9), 1537-1551. http://dx.doi.org/10.1111/jgs.12420.

van Kan, G. A., Rolland, Y., Houles, M., Gillette-Guyonnet, S., Soto, M., \& Vellas, B. 
(2010). The assessment of frailty in older adults. Clinics in Geriatric Medicine, 26(2), 275-286. http://dx.doi.org/10.1016/j.cger.2010.02.002.

van Kempen, J. A. L., Schers, H. J., Philp, I., Olde Rikkert, M. G. M., \& Melis, R. J. F. (2015). Predictive validity of a two-step tool to map frailty in primary care. BMC Medicine, 13(1), 1-9. http://dx.doi.org/10.1186/s12916-015-0519-9.

van Kempen, J., Schers, H., Jacobs, A., Zuidema, S., Ruikes, F., Robben, S., et al. (2013). Development of an instrument for the identification of frail older people as a target population for integrated care. British Journal of General Practice, 63(608), 225-231. http://dx.doi.org/10.3399/bjgp13X664289.

van Oostrom, S. H., Van Der A, D. L., Rietman, M. L., Picavet, H. S. J., Lette, M., Verschuren, W. M. M., et al. (2017). A four-domain approach of frailty explored in the Doetinchem cohort study. BMC Geriatrics, 17(1), 1-11. http://dx.doi.org/10 1186/s12877-017-0595-0.

Vernerey, D., Anota, A., Vandel, P., Paget-Bailly, S., Dion, M., Bailly, V., et al. (2016). Development and validation of the FRAGIRE tool for assessment an older person's risk for frailty. BMC Geriatrics, 16(1), 1-28. http://dx.doi.org/10.1186/s12877-0160360-9.

Walston, J. D., \& Bandeen-Roche, K. (2015). Frailty: A tale of two concepts. BMC Medicine, 13(1), 185. http://dx.doi.org/10.1186/s12916-015-0420-6.

Woo, J., Goggins, W., Sham, A., \& Ho, S. C. (2005). Social determinants of frailty. Gerontology, 51(6), 402-408. http://dx.doi.org/10.1159/000088705.

Woo, J., Zheng, Z., Leung, J., \& Chan, P. (2015). Prevalence of frailty and contributory factors in three Chinese populations with different socioeconomic and healthcare characteristics. BMC Geriatrics, 15(1), 163. http://dx.doi.org/10.1186/s12877-0150160-7.

Yamanashi, H., Shimizu, Y., Nelson, M., Koyamatsu, J., Nagayoshi, M., Kadota, K., et al. (2015). The association between living alone and frailty in a rural Japanese population: The Nagasaki Islands study. Journal of Primary Health Care, 7(4), 269-273. http://dx.doi.org/10.1186/1880-6805-32-10.

Yeolekar, M. E., \& Sukumaran, S. (2014). Frailty syndrome: A review. Journal of Association of Physicians of India, 62(November), 34-38.

Yesavage, J. (1988). Geriatric depression scale. Psychopharmacology Bulletin, 24(4), 709-711.

Young, A. C. M., Glaser, K., Spector, T. D., \& Steves, C. J. (2016). The identification of hereditary and environmental determinants of frailty in a cohort of UK twins. Twin Research and Human Genetics, 19(6), 600-609. http://dx.doi.org/10.1017/thg. 2016.72.

Zaslavsky, O., Cochrane, B. B., Thompson, H. J., Woods, N. F., Herting, J. R., \& LaCroix, A. (2012). Frailty: A review of the first decade of research. Biological Research For Nursing, 15(4), 422-432. http://dx.doi.org/10.1177/1099800412462866. 